\title{
Assessing the Impacts of Land Use-Cover Change on Hydrology of Melka Kuntrie Subbasin in Ethiopia, Using a Conceptual Hydrological Model
} Yitea Seneshaw Getahun ${ }^{* *}$ and Van Lanen HAJ²

${ }^{1}$ Department of Natural Resources Management, Debre Berhan University, Ethiopia

${ }^{2}$ Hydrology and Quantitative Water Management Group, Centre for Water and Climate, Wageningen University, Wageningen, The Netherlands

\begin{abstract}
The growth of population and its effect on the land use-cover change have been influencing the hydrology of the sub basin by changing the magnitude of stream flow and groundwater flow. In this paper, the likely land use-cover change impacts on hydrology of the Melka Kuntrie sub basin in the Upper Awash River Basin have been evaluated using the semi-distributed HBV hydrological model and Landsat imageries for two different periods. ArcGIS was used to generate the land use-cover maps from Landsat 5 TM and 7 ETM+ acquired, in the year 1986 and 2003, respectively. The land use-cover maps were generated using the Maximum Likelihood Algorithm of Supervised Classification. The accuracy of the classified maps was assessed using contingency matrix. The result of this analysis showed that the cultivated land has expanded from 1986 to 2003 . The land use in 2003, which was mostly converted to agriculture land from forest, grass, or shrub land, showed an increased stream flow in the main rainy season, while the stream flow in dry or small rainy season indicted inconsistency from month to month. In the same time, there was a decrease in evapotranspiration in 2003 land use. The stream flow increased by the 2003 land use was $25 \%$ in June, $4 \%$ in July, $6 \%$ in August and $9 \%$ in September that corresponded to $0.065 \mathrm{~mm} /$ day in June, $0.077 \mathrm{~mm} /$ day in July, $0.07 \mathrm{~mm} /$ day in August and $0.039 \mathrm{~mm} /$ day in September for the main rainy season as compared to the 1986 land use. The model calibration was carried out using observed hydrometeorological data from 1991 to 2004 and the validation period was from 2005 to 2008 . The performance of the HBV model for both calibration and validation was reasonable well and the Nash-Sutcliffe efficiency was 0.86 and 0.78 for calibration and validation, respectively.
\end{abstract}

Keywords: Melka kuntrie sub basin; HBV model; Hydrology; Impacts ofland use-cover change; Landsat imageries; Hydrometeorological data

\section{Introduction}

The agricultural based economy and rapidly increasing human population are the main cause of land use-cover change in the developing countries [1]. Resource scarcity is also the main cause of Land use-cover change and largely driven by the decision of the people, population growth, declining household farm size and income [2]. These land use-cover change have significant influence on quantity or quality of stream flow $[1,3,4]$. Different studies that have been carried out in many parts of Ethiopia indicated that croplands have expanded at the expense of natural vegetation, forests and shrub lands [5-10]. The Land use-cover change has negative consequence in hydrological system of a sub basin [11].

High population growth, deforestation, traditional agriculture techniques, land use-cover change, and improper use of land have resulted in massive land degradation with water scarcity [12]. Population growth often results into an increase of water need and land for agriculture, while land use-cover change has an impact on the hydrology of a basin. Today, many rural families can barely make their living from agriculture because of the consequences of rapid deforestation, degradation of land resources, water scarcity, and loss of fertility in their agricultural land [12]. The major effects of land usecover change is likely to alter the hydrologic response of sub basin and change in water availability $[10,13,14]$. The Land cover under little vegetation is subjected to high surface runoff and low water retention [1]. Whereas, the high vegetation covers increase, evapotranspiration and decrease the mean annual river flow. The Land use-cover plays a fundamental role in driving hydrological processes within a sub basin [15]. These include changes in water demands such as irrigation, changes in water supply from altered hydrological processes of infiltration, groundwater recharge, and runoff, and changes in water quality from agricultural runoff [16]. Therefore, a far better understanding of land use-cover change, its effect, and interaction to the hydrology of a basin is highly essential.

Small-scale sub basin based hydrological information considering land use-cover change is crucial for stream flow assessment for irrigated agriculture or any use of water. It is very clear that water availability is becoming a critical factor in so many sectors, so that assessing the anticipated impacts of land use-cover change on hydrology is unquestionable $[17,18]$. Irrigation schemes in the Upper Awash River Basin have been very functional for many years, but reservoirs are becoming to be filled with sediment and therefore storage capacity is decreasing [19]. Water management in the basin is becoming very difficult that needs assessment on a regular basis because of the reduction in storage capacity, variability of rainfall, and high water demand. The basin also faced recurrent flood during the rainy season, which results in loss of life, and property damage, while at the end of the dry season there was insufficient water in the basin to meet the demand of irrigated agriculture or other purpose [20].

*Corresponding author: Yitea Seneshaw Getahun, Department of Natural Resources Management, Debre Berhan University, Ethiopia, Tel: +251911522905; E-mail: yiseneshaw@gmail.com

Received July 15, 2015; Accepted August 10, 2015; Published August 17, 2015

Citation: Getahun YS, Van Lanen HAJ (2015) Assessing the Impacts of Land Use-Cover Change on Hydrology of Melka Kuntrie Subbasin in Ethiopia, Using a Conceptual Hydrological Model. Hydrol Current Res 6: 210. doi:10.4172/21577587.1000210

Copyright: (c) 2015 Getahun YS, et al. This is an open-access article distributed under the terms of the Creative Commons Attribution License, which permits unrestricted use, distribution, and reproduction in any medium, provided the original author and source are credited. 
Citation: Getahun YS, Van Lanen HAJ (2015) Assessing the Impacts of Land Use-Cover Change on Hydrology of Melka Kuntrie Subbasin in Ethiopia, Using a Conceptual Hydrological Model. Hydrol Current Res 6: 210. doi:10.4172/2157-7587.1000210

Page 2 of 11

The Landsat 5 TM and Landsat 7 ETM+ were Level 1T (terrain corrected), which means that those images have been corrected for geometric and radiometric correction. Band combination of 2, 3 and 4 from both imageries were used for the land use-cover analysis [21-23]. From the standard "false color" composite of band 2, 3 and 4 vegetation appears in shades of red, urban areas are cyan blue, and soils vary from dark to light browns. Ice, snow and clouds are white or light cyan [23]. For image, enhancement and classification the most common nonlinear Histogram Equalize Stretch and Supervised Maximum likelihood Classification were used, respectively [24-28]. Thematic image accuracy has been also evaluated how well the class name on the map correspond to what is really on the ground $[29,30]$.

In summary, since the changing land use-cover and its impact on hydrological processes are a widespread concern and a great challenge, it is vital to understand the impact of land use-cover change on future hydrology in the Melka Kuntrie sub basin using a hydrological model that is fed with hydrometeorological data. The main objective of this study is to assess the expected changes in stream flow in the Melka Kuntrie sub basindue to the changing land use-cover using the conceptual rainfall-runoff hydrological HBV model and ArcGIS. Landsat imageries were analyzed to investigate land use-cover change using ArcGIS.

\section{Description of study area}

Location: The geographic location of the Awash River Basin is between $7^{\circ} 53^{\prime} \mathrm{N}$ and $12^{\circ} \mathrm{N}$ latitudes and $37^{\circ} 57^{\prime} \mathrm{E}$ and $43^{\circ} 25^{\prime} \mathrm{E}$ of longitudes [31]. The largest part of the Awash River Basin is located in the arid lowlands of the Afar Region in the northeastern part of Ethiopia. However, Melka Kuntrie sub basin located in the Upper Awash River Basin (Figure 1). The upper part of the Awash River Basin that is Melka Kuntrie sub basin is the study area of this research. It lies upstream of Koka dam. The Melka Kuntrie sub basin covers about 4456 $\mathrm{km}^{2}$ with particular geographical location of 8:42: $0 \mathrm{~N}$ and 38:36: $0 \mathrm{E}$.
Climate: The movement of the inter-tropical convergence zone (ITCZ) and the influence of the Indian Monsoon throughout the year, mainly determine the climate pattern of the Melka Kuntrie sub basin [32]. There are three seasons in the Melka Kuntrie sub basin based on the movement of inter-tropical convergence zone (ITCZ), the amount of rainfall and the rainfall timing. The three seasons are Kiremt, which is the main rainy season (June-September), Bega, which is the dry season (October-January), and Belg, the small rainy season (FebruaryMay) [33]. The mean annual rainfall over the Meka kuntrie sub basin is $1216 \mathrm{~mm}$.

As shown in Figure 1, the traditional climate classification based on a digital elevation model, indicated that there is a dominant Woinadega (Subtropical) climate in the southwestern, southeastern highlands and upper basin part of the river basin. The traditional climate classification zone of the region based on elevation, indicated that Kola (hot dry tropical) is between $1500-1800 \mathrm{~m}$ a.s.l, the WoinaDega (subtropical) is between 1800-2400 m a.s.l, the Dega (temperate) is between 2440-3500 $\mathrm{m}$ a.s.l, and the Wurch (alpine) is over $3500 \mathrm{~m}$ a.s.l [34].

Land use and soils: The common land use types in the Meka kuntrie sub basinare cultivated agricultural land, grassland, cropland with shrub land and forestland. The Meka kuntrie sub basinconsists of different soil types. The most common soil types are Cambisols and Vertisols. The Vertisolsare dominated by the montomorillonite clay mineral. This clay mineral expands when there is a wet condition and shrinks when there is a dry condition, causing cracks at the surface in the dry season [35].

Methodology and data: The conceptual semi-distributed rainfallrunoff HBV "Light" Model, ArcGIS 10.1, and otherstatistical tools were used to analyze Landsat imageries, GIS files, observed hydro meteorological data. The impact of land use-cover change on stream flow of the basin was assessed by statistical analysis of model output of hydrometeorological variables.

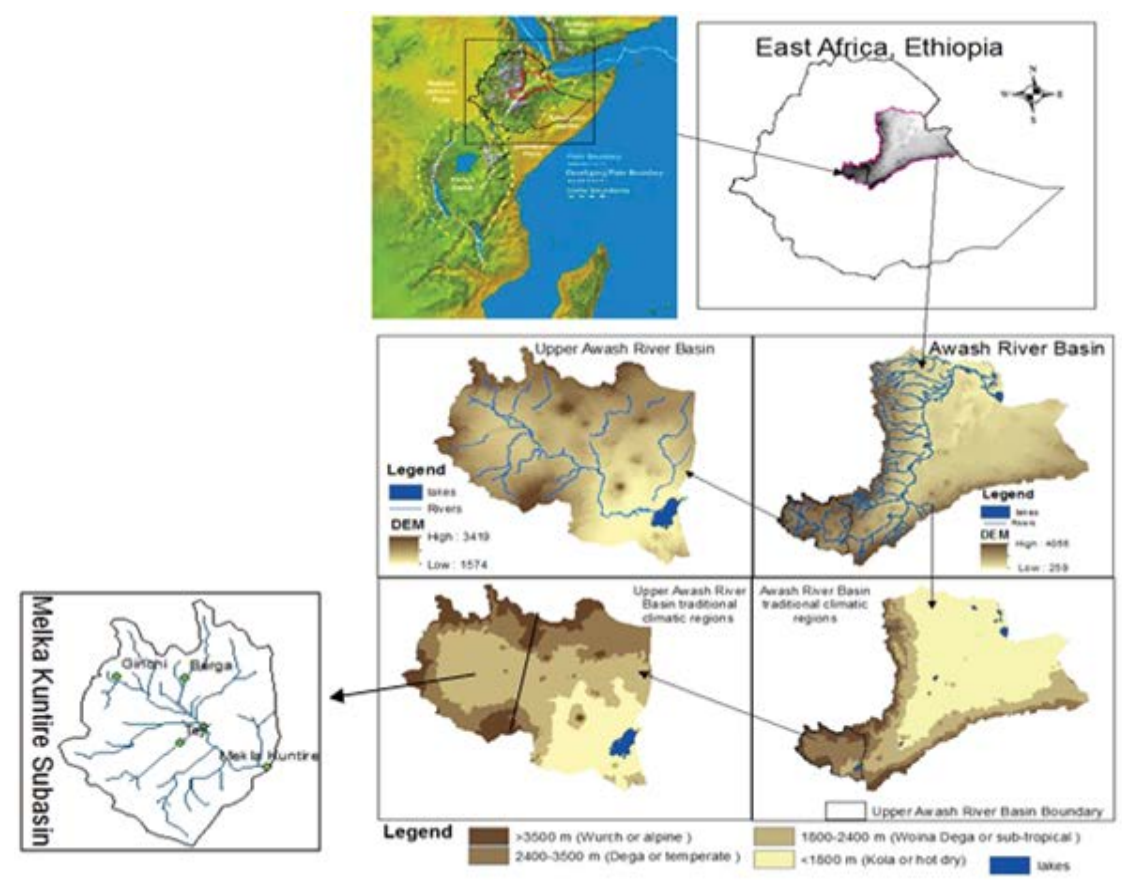

Figure 1: Study area with traditional climatic regions based on DEM (Upper left figure taken from James, 2014). 
Approach: The Landsat TM and ETM+ imageries were selected for the year 1986 and 2003, respectively and processed using GIS for the land use-cover change analysis as shown in Figure 2. Accuracy of the classified land use-cover classes were verified with the set of referenced points. The observed hydro meteorological data were organized according to the requirements of the HBV model. Multiple elevation zones up to 18 with the interval of $100 \mathrm{~m}$, and two vegetation zones were used for the HBV model calibration. After the HBV model calibration, validation and knowing that the model efficiency is good based on observed hydro meteorological datasets, the next step was the land use-cover change assessment using some reference period and changing the vegetation coverage based the change detection results. Finally, the land use-cover change impact on hydrology of the Melka Kuntrie sub basin were analyzed (Figure 2).

\section{Data and data analysis}

Landsat imageries: Landsat imageries of different bands were downloaded and analyzed using ArcGIS to identify the land usecover change in the Melka Kuntrie sub basin. The two imageries of Landsat 5 TM and Landsat 7 ETM+ were downloaded from the United State Geological Survey (USGS) earth explorer in Geo TIFF format. The Digital Elevation Model (DEM) and Land use-cover were also downloaded from the USGS and Corn Land Cover Facility (GLCF), respectively. Landsat 7 ETM+ image for the year 2003 and Landsat 5 TM image for the year 1986 were processed to detect the land use-cover change between those years.Landsat 5 TM was acquired on January 12th, 1986 and Landsat 7 ETM+ was acquired on February 23th, 2003, with the WRS-2 path/row for both imageries of 168 and 169/54.The timing of both images was as close as possible that is in the same annual season to circumvent a seasonal variation in vegetation pattern.

The spatial resolution is $30 \mathrm{~m}$ for all bands apart from band 6 that has a spatial resolution of 120 meters (TM 5) and $60 \mathrm{~m}$ (ETM+) (Table 1). Landsat 7 is equipped with an Enhanced Thematic Mapper Plus (ETM+), the successor of TM. The observation bands are essentially the same seven bands as TM, and the newly added panchromatic band 8 , with a high resolution of $15 \mathrm{~m}$ was added.

The accuracy of a classified image refers to the extent to which it agrees with a set of reference data. Most quantitative methods to assess classification accuracy involve an error matrix built from the two datasets, which are remotely sensed map classification and the Google Earth reference data. The reference data was taken from Google Earth. Reference data were collected for each class type and compare against the classified image using a contingency matrix (Table 2). Overall map

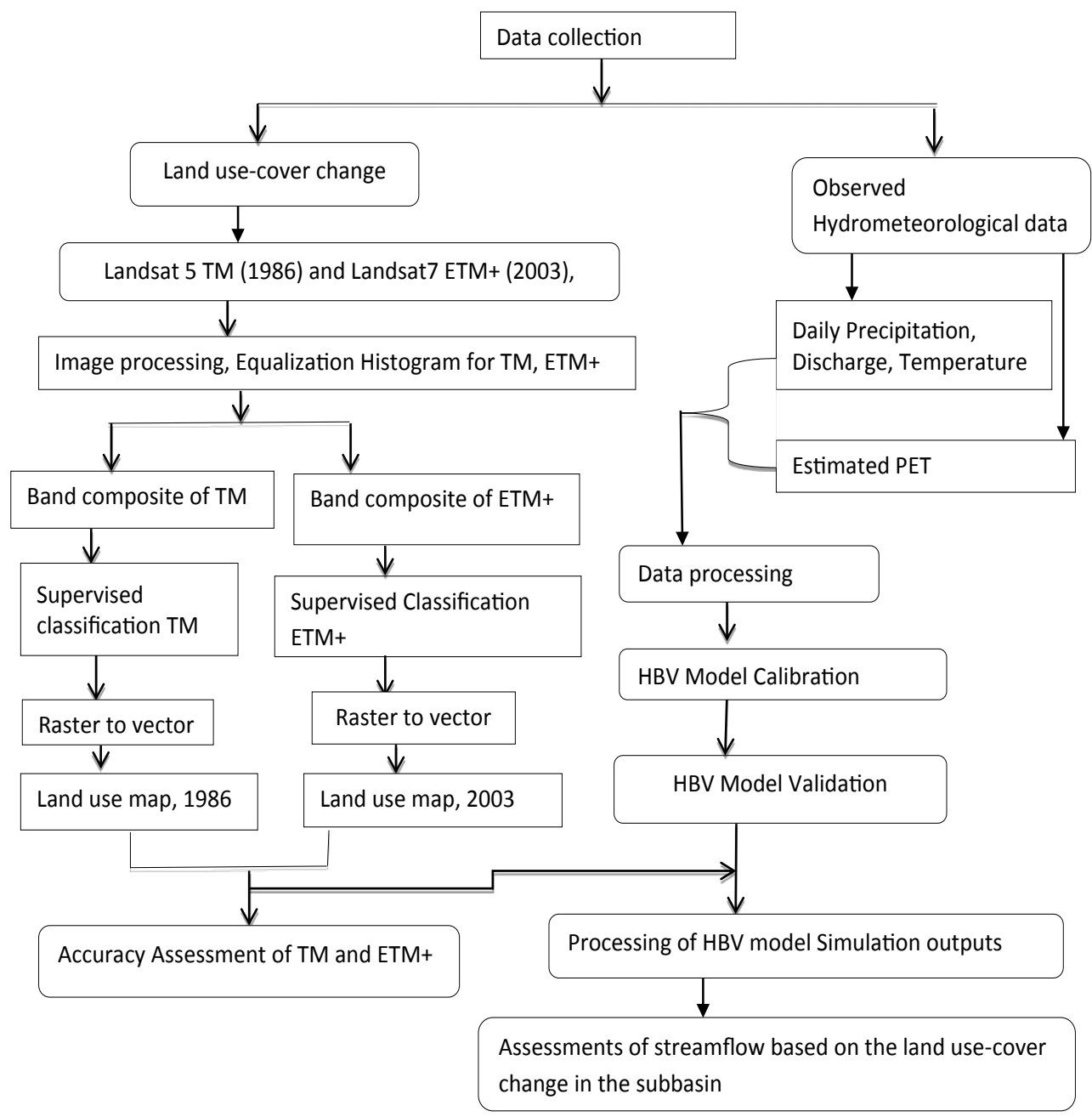

Figure 2: General methodology. 
Citation: Getahun YS, Van Lanen HAJ (2015) Assessing the Impacts of Land Use-Cover Change on Hydrology of Melka Kuntrie Subbasin in Ethiopia, Using a Conceptual Hydrological Model. Hydrol Current Res 6: 210. doi:10.4172/2157-7587.1000210

Page 4 of 11

\begin{tabular}{|c|c|c|c|c|}
\hline Bands & Description & $\begin{array}{c}\text { Spatial } \\
\text { resolution }(\mathbf{m})\end{array}$ & $\begin{array}{c}\text { Spectral } \\
\text { resolution } \\
(\boldsymbol{\mu m})\end{array}$ & $\begin{array}{c}\text { Temporal } \\
\text { resolution } \\
\text { (days) }\end{array}$ \\
\hline 1 & Blue & 30 & $0.45-0.515$ & 16 \\
\hline 2 & Green & 30 & $0.525-0.605$ & 16 \\
\hline 3 & Red & 30 & $0.63-0.69$ & 16 \\
\hline 4 & Near Infrared & 30 & $0.75-0.90$ & 16 \\
\hline 5 & Short-wave Infrared & 30 & $1.55-1.75$ & 16 \\
\hline 6 & Thermal Infrared & $\begin{array}{c}120(\mathrm{TM}) 60 \\
\text { (ETM) }\end{array}$ & $10.40-12.5$ & 16 \\
\hline 7 & Short-wave Infrared & 30 & $2.09-2.35$ & 16 \\
\hline 8 & Panchromatic & 15 & $0.52-0.90$ & 16 \\
\hline
\end{tabular}

Table 1: Landsat 5 TM and ETM+ Sensor specification.

\begin{tabular}{|c|c|c|c|c|}
\hline \multirow{2}{*}{ Classified image } & \multicolumn{4}{|c|}{ Referenced data } \\
\cline { 2 - 5 } & Agriculture & $\begin{array}{c}\text { Grass/shrub } \\
\text { land }\end{array}$ & Forest & Total \\
\hline Agriculture & 24 & 3 & 0 & 27 \\
\hline Grass/shrub land & 4 & 22 & 3 & 29 \\
\hline Forest & 1 & 2 & 25 & 28 \\
\hline Total & 29 & 27 & 28 & 84 \\
\hline
\end{tabular}

Table 2: Accuracy assessment using a contingency matrix.

accuracy was computed by dividing the total correct (obtained by summing the major diagonal of the error matrix) by the total number of pixels in the error matrix. Error of omission is the percentage of pixels that should have been put into a given class but were not. Error of commission indicates pixels that were placed in a given class when they actually belong to another (Figure 3).

Many ways are available to look at the thematic accuracy of a classified image. The overall, producer, and user accuracy criteria were investigated for the classified image.

Overall accuracy

Correctly classified is the diagonal values which is $=24+22+25=71$

Total number of reference $=84$

Overall accuracy $=(71 / 84)^{\star} 100 \%=84 \%$

Errors of omission are the type on the ground is not that type on the classified image - the real type is omitted from the classified image.

Errors of omission for Agriculture land $=1+4=(5 / 29)^{\star} 100 \%=17 \%$

For grass/shrub land $=3+2=(5 / 27) * 100 \%=18 \%$

For Forest $=0+3=(3 / 28)^{\star} 100 \%=10 \%$

Error of omission for agriculture, grass/shrub land and forest were 17, 18 an 10 percent respectively, indicating that all 29, 27 and 28 reference pixels for agriculture, grass/shrub land and forest were categorized well which means above $80 \%$ producers accuracy.

Producer's accuracy $=100 \%$ - error of omission $(\%)$

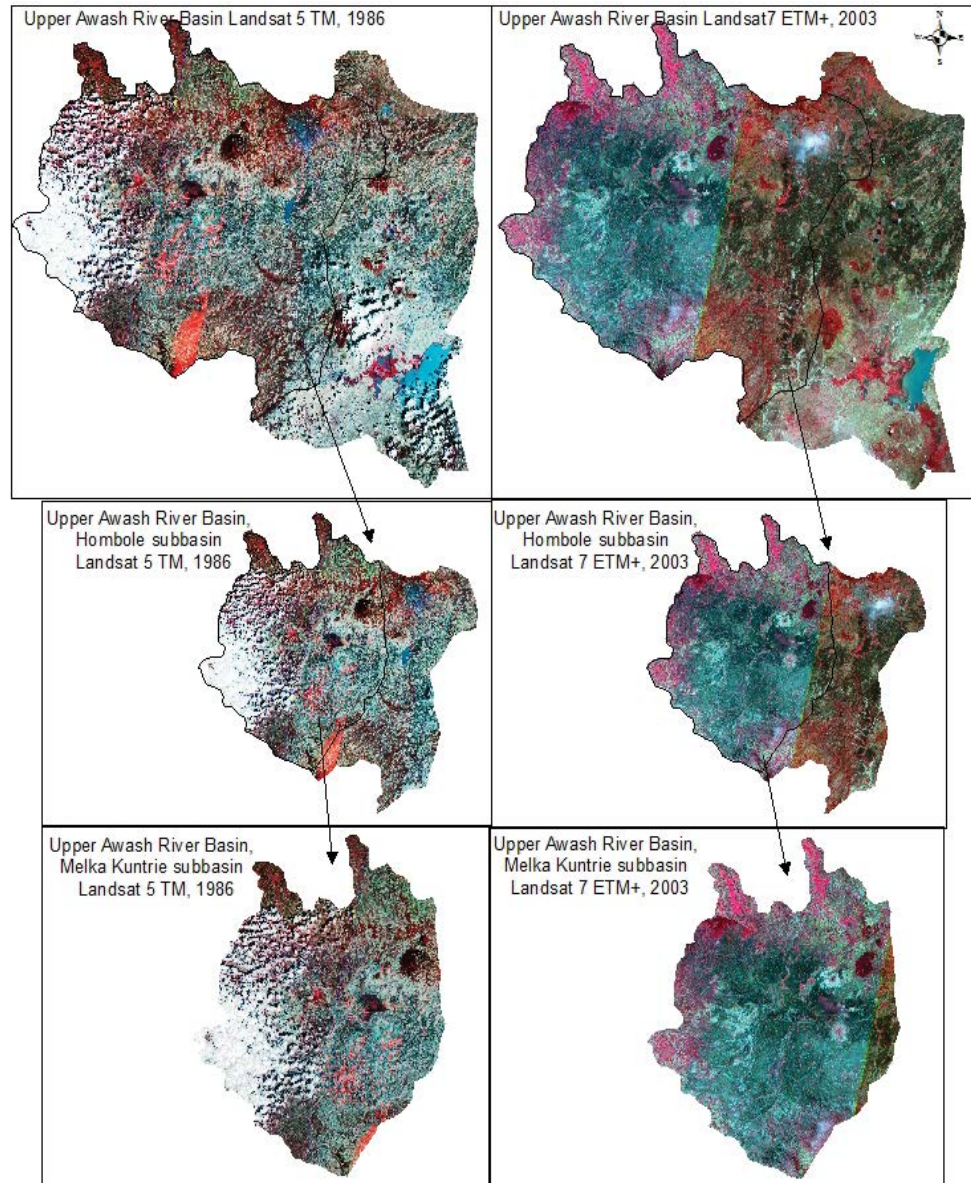

Figure 3: The Standard "False Color" composite image of the Hombole and Melka Kuntrie subbasin of the year 1986 and 2003 
Errors of commission represent pixels that belong to another class but are labeled as belonging to the class

Errors of commission for Agriculture $=0+4=(4 / 30)^{\star} 100 \%=13 \%$

For grass/shrub land $=3+3=(6 / 29) * 100 \%=20 \%$

For Forest $=1+2=(3 / 23)^{\star} 100 \%=13 \%$

User's accuracy $=100 \%$ - error of commission $(\%)$

User's accuracy or reliability is indicative of the probability that a pixel classified on the map/image actually represents that category on the ground.

\section{Model calibration (1991-2004) and validation (2005-2008)}

The HBV model was calibrated using observed hydro meteorological data for the Melka Kuntrie sub basin from the period (1991-2004) and the Nash-Sutcliffe model efficiency (NS)was 0.87 . Whereas, the validation Nash-Sutcliffe model efficiency was 0.78 . The HBV model performance for the calibration and validation period was reasonably well for the Melka Kuntrie sub basin.

The observed versus simulated stream flow hydrograph for the calibrated period (Figure 4) indicate that the HBV model underestimated the high flow and overestimated the low flow in the Melka Kuntrie sub basin in most of the years, excluding the years 1995 and 2004 for high flow. The underestimation of high flow in many years may be attributed to data quality, the less ability of the HBV model to characterize the sub basin, orographic enhanced intense and high amount of precipitation, soil type in the sub basin. The overestimation that happened in the low flow may be attributed to the human influence in the sub basin; there are a lot of small scale irrigation system and water extraction for different purposes. The Melka Kuntrie sub basin total mean stream flow was $199.56 \mathrm{~mm} /$ year and $196.34 \mathrm{~mm} /$ year for observed and simulated, respectively.

The model performance in the validation period were slightly poorer compared with the results of the calibration period. The observed versus simulated stream flow hydrograph for the validation period (Figure 5) indicate a similar pattern as for the calibration hydrograph of HBV model that underestimate the high flow and overestimate the low flow.

\section{Results and Discussions}

Forest, shrub/grass, and agricultural land were the major land usecove types in the Melka Kuntrie sub basin. The classified forest, shrub/ grass, and agricultural land use-cover types for the Melka Kuntrie sub basin indicated that most of the forest and shrub/grass lands that were in the 1986 converted into agricultural land in the year 2003 (Figures 6 and 7). Agricultural expansion was the major driver of land use change in the Melka Kuntrie sub basin. There was more shrub/grass land in 1986 than in 2003, which approached the area of agricultural land though the agricultural land was the largest in both years. Besides, the conversion of forest land into agricultural land there was also a largest area of shrub/grass land in 1986 that converted into agricultural land for the 2003 land use-cover (Figures 6 and 7).

The land use-cover map for the year 1986 in Figures 6 and 7 showed that there was about $19 \%, 45 \%$, and $36 \%$ forest, agricultural and shrub/ grass land, respectively. However, the land use- cover map for 2003 showed that $11 \%, 63 \%$, and $23 \%$ was forest, agricultural and shrub/
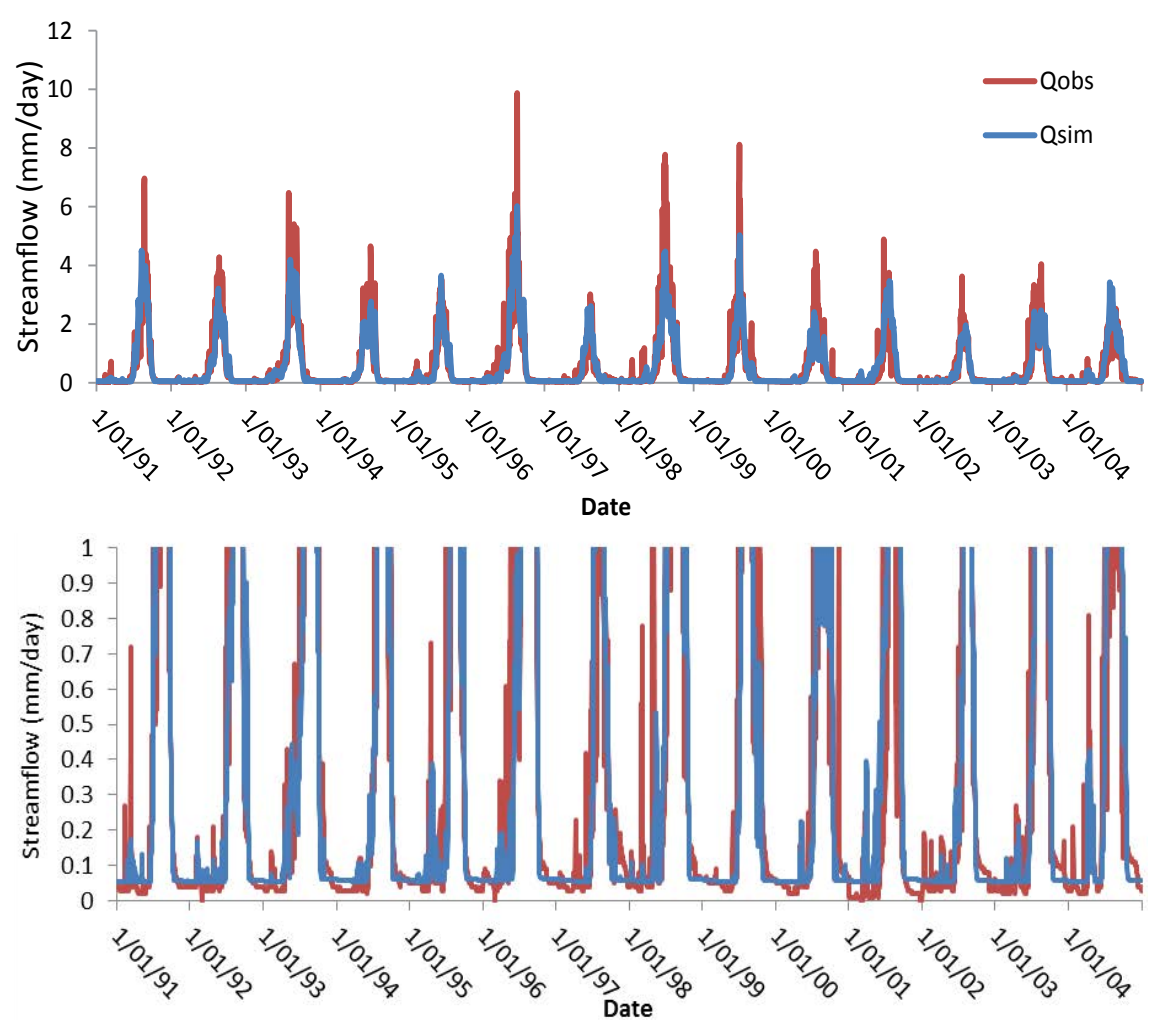

Figure 4: The observed and simulated streamflow in the Melka Kuntrie subbasin for the calibration period (1991-2004), the lower pannel indicates the zoomed in observed and simulated streamflow. 

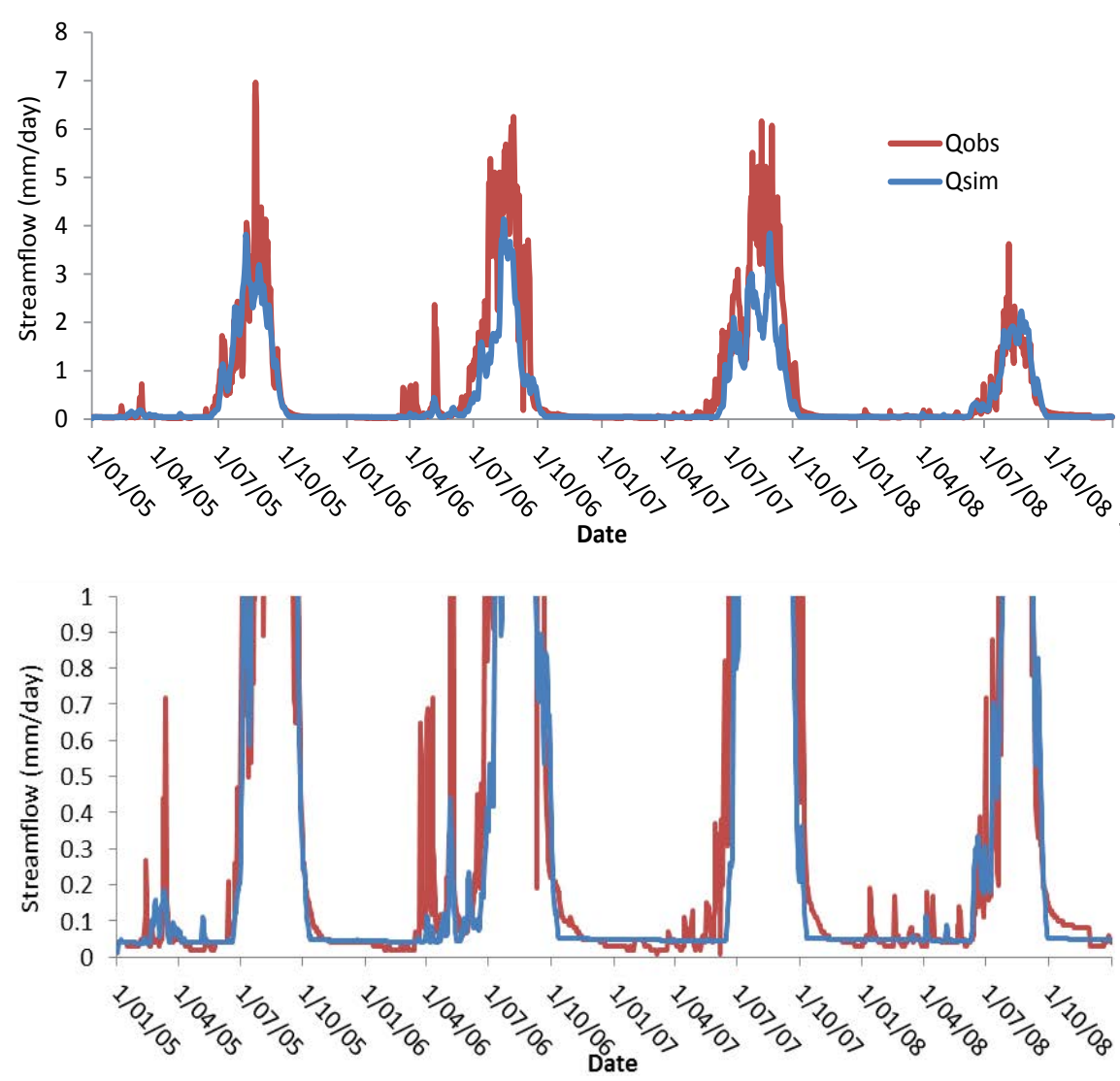

Figure 5: The observed and simulated streamflow in the Melka Kuntrie subbasin for validation periods (2005-2008),the lower pannel indicates the zoomed in observed and simulated streamflow.

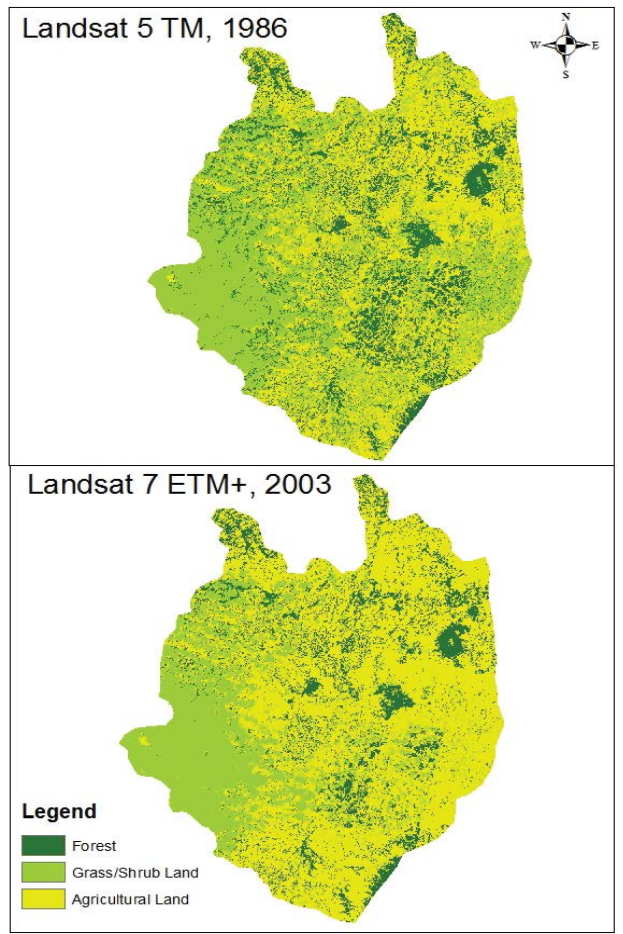

Figure 6: Land use cover map for the year 1986 (upper) and 2003 (lower) for the Melka Kuntrie subbasin derived from Landsat images. 
Citation: Getahun YS, Van Lanen HAJ (2015) Assessing the Impacts of Land Use-Cover Change on Hydrology of Melka Kuntrie Subbasin in Ethiopia, Using a Conceptual Hydrological Model. Hydrol Current Res 6: 210. doi:10.4172/2157-7587.1000210
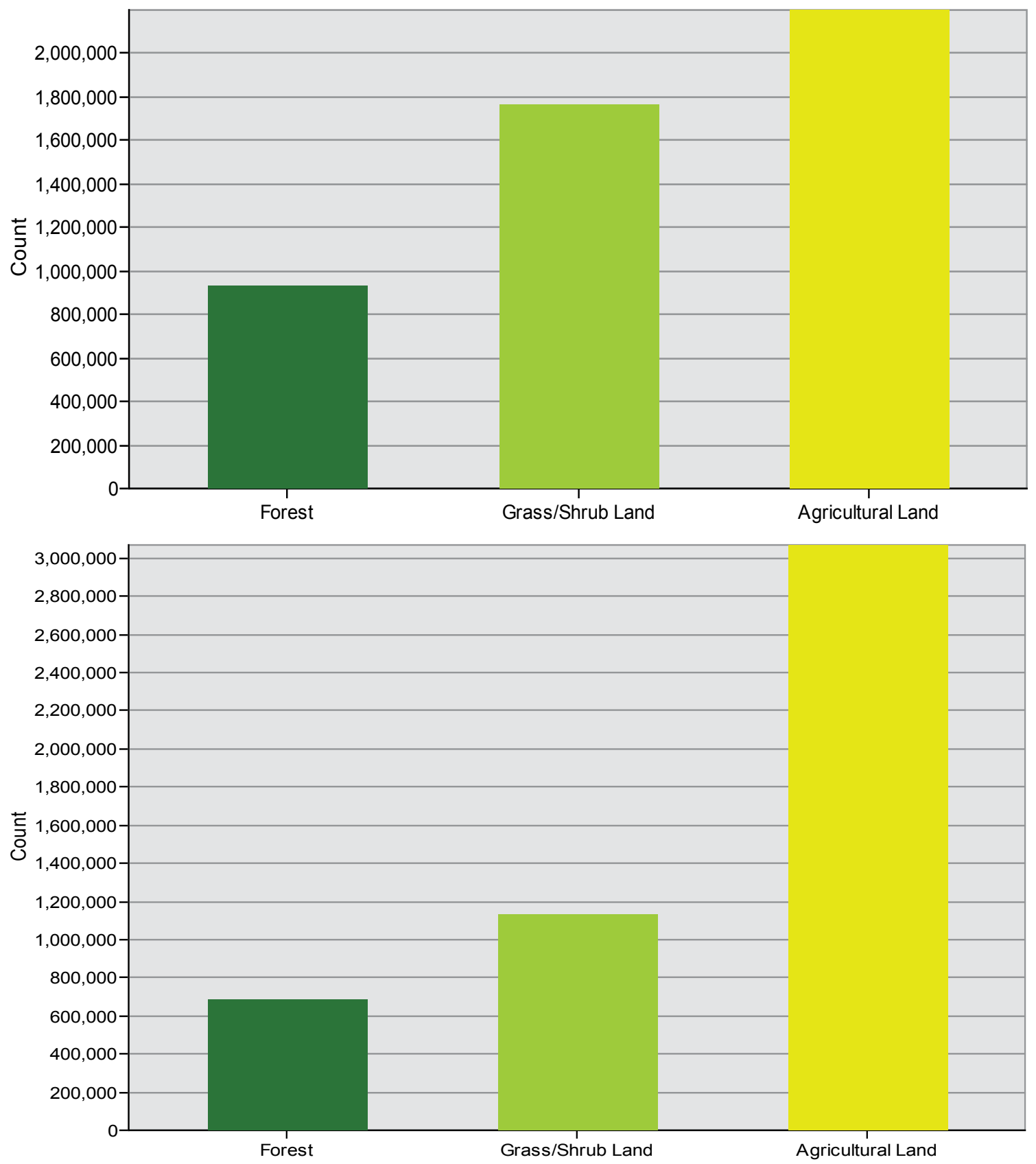

Figure 7: Land use-cover of the Melka Kuntrie subbasin obtained from Landsat images in the year 1986 for Landsat TM (upper) and in the year 2003 for Landsat ETM+ (lower).

grass land, respectively. The large area of forest and shrub/grassland area in the sub basin was partly changed into agricultural land. There was only small forest coverage left in the north and central part of the sub basin.

\section{Hydrological response to the land use-cover change}

The HBV model was re-calibrated for 1990-2008 period using the corn land use and the following runs were performed without calibration by only changing the land use-cover type. The meteorological forcing of this period was used for the HBV model to simulate stream flow and evapotranspiration using the 1986 and 2003 land use-cover types for the Melka Kuntrie sub basin. Based on the land use-cover type in 1986 and 2003, the HBV model was forced by keeping the other parameters and meteorological variables as it was in the calibration period. In other words, the parameter and meteorological variables were kept constant. The simulated stream flow response due to the change in vegetation based on 1986 and 2003 data were processed for different seasons. During the main rainy season, there was slightly increased stream flow for the 2003 land use as compared to the 1986 land use due to the expansion of agriculture land (Figure 8). For the dry season, the simulated stream flow for the 1986 and 2003 land use showed some variability in the flow differences. 


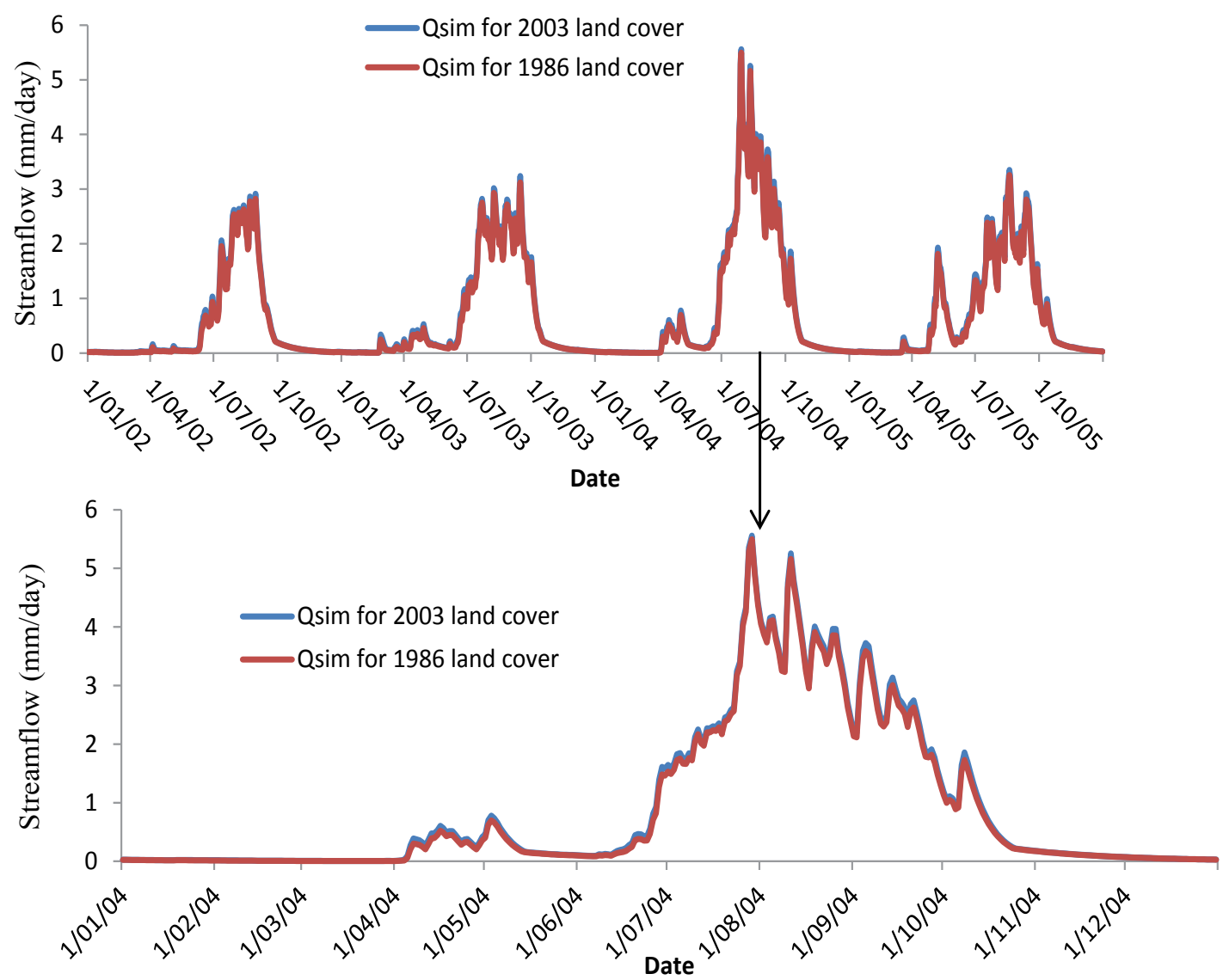

Figure 8: Simulated streamflows for the year 2004 (lower panel) and for 2002-2005 (upper panel), using the 1986 and 2003 land cover for the Melka Kuntrie subbasin.

\section{Impacts of land use-cover change on stream flow and evapotranspiration}

As indicated in Figures 8 and 9, there was a slightly higher stream flow for the 2003 land cover than for the 1986 land cover. Because of the decrease in forest or shrub/grass land cover the rainfall in 2003 land cover could easily increase the stream flow and there are slightly higher stream flow in 2003 land cover relative to 1986.In the case of the 1986 land cover type, the larger part of the rainfall was lost to evapotranspiration and that is why the stream flow was slightly lower than 2003 land cover especially in the main rainy season as shown in the (Figure 10).

For themain rainyseason, the streamflowincreasein the2003land use was $8 \%$ in June, $4 \%$ in July, $5 \%$ in Augustand $3 \%$ in September ascompared to the 1986 land use, which corresponds to $0.3,0.6,0.11$, and $0.5 \mathrm{~mm} /$ day, respectively. The evapotranspiration increase for the 1986 land use was 3\% in June, 7\% in July, 9\% in August and 3\% in Septembers compared to the 2003 land use, which corresponds to $0.06,0.23,0.37$, and $0.11 \mathrm{~mm} /$ day, respectively. The small rainy season stream flow increase for the 2003 land use as compared to the 1986 land cover was $12 \%$ in April and 9\% in May that corresponds to 0.01 and $0.02 \mathrm{~mm} /$ day daily mean stream flow. The rest small rainy season two months showed decreased stream flow for the 2003 land use as compared to the 1986 land use that was $9 \%$ in February and $11 \%$ in March corresponding to very slow stream flow 0.003 and $0.006 \mathrm{~mm} /$ day, respectively.

The dry season stream flow for the 2003 land use showed decreasing trends in most of the months as compared to the 1986 land cover for the period 1990-2008. The stream flow decrease for the 2003 land use as compared to the 1986 land use was 15\% in January, 13\% in November and $9 \%$ in December corresponding to very small flows $0.0007,0.06$ and $0.0007 \mathrm{~mm} /$ day, respectively. The month October showed an increasing stream flow for the 2003 land use cover as compared to the 1986 land use cover, which was $8 \%$ corresponding to the $0.005 \mathrm{~mm} /$ day.

\section{Extreme Land use-cover change scenarios and their impact on simulated stream flow}

Two extreme scenarios were defined that is a completely forested and a completely non-forested Melka Kuntrie sub basin. For the main rainy season, the completely non-forested scenario showed that the daily mean stream flow increased by $2 \%$ in June, $13 \%$ in July, $14 \%$ in August and 7\% in September as compared to the completely forested sub basin. This implied that there was $0.01,0.23,0.35$, and $0.12 \mathrm{~mm} /$ day increase of daily mean stream flow for June, July, August, and September, respectively due to the complete deforestation relative to the forested one as shown in the Figure 11. The change in stream flow was due to an increased evapotranspiration for the forested scenario as compared to the deforested scenario as shown in the Figure 12. The increased evapotranspiration loss for the completely forested scenario was $8 \%$ in June, $14 \%$ July $7 \%$ August and $9 \%$ in September that corresponds to $0.20,0.52,0.28$ and $0.35 \mathrm{~mm} /$ day in stream flow loss, respectively for the forested scenario as compared to the completely deforested scenario. 


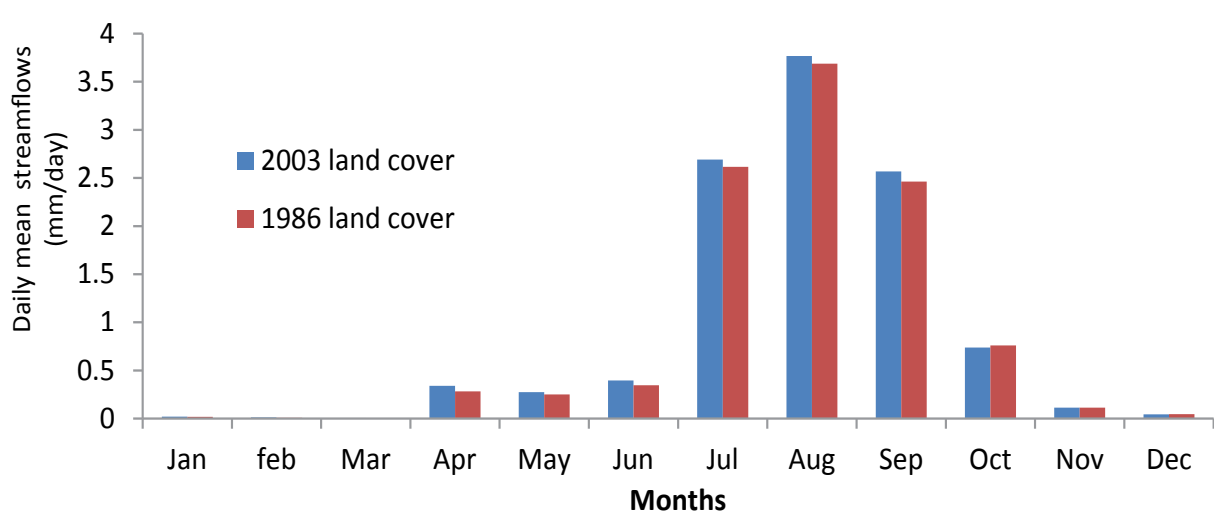

Figure 9: Simulated streamflow for the 2003 and 1986 land cover for the year 2004.

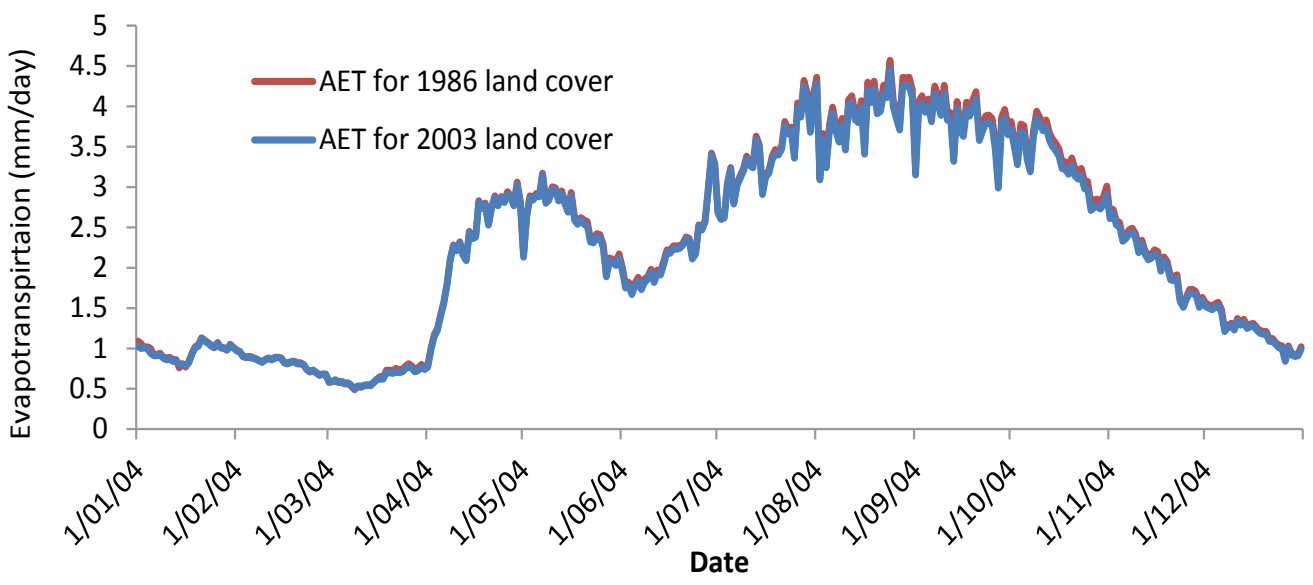

Figure 10: Evapotranspiration in the 2004 for 1986 and 2003 land cover.

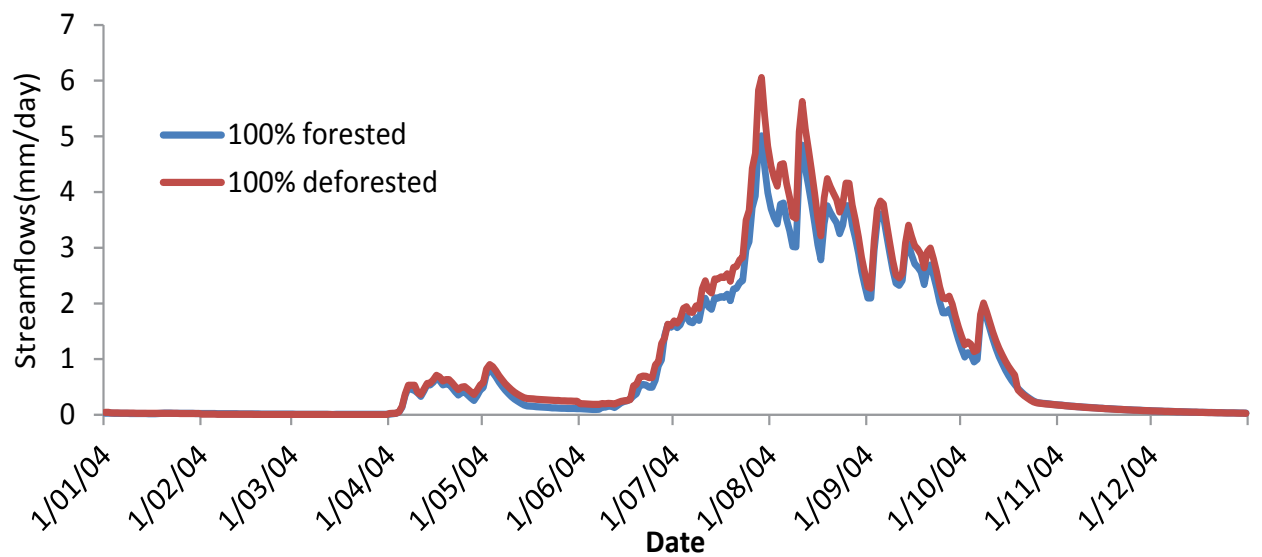

Figure 11: Simulated streamflow for the year 2004 for the completely forested and completely deforested land cover scenarios.

The daily mean stream flow for the small rainy season indicated that there was also increasing stream flow for the completely deforested scenario as compared to the completely forested scenario in all months, excluding February. In the dry season, the differences in flow between the forested and deforested scenarios were variable, but very small.

The $100 \%$ deforested extreme scenario indicated that there is higher stream flow in the main rainy season and decreased evapotranspiration, while the $100 \%$ forested scenarios showed the reverse. For the $100 \%$ forested extreme scenario the evapotranspiration change was more noticeable in the small and main rainy seasons. For the $100 \%$ deforested extreme scenario the stream flow increase was more noticeable in the main rainy season. Overall, for the main rainy season there was an increasing daily mean stream flow for the 2003 land use as compared 


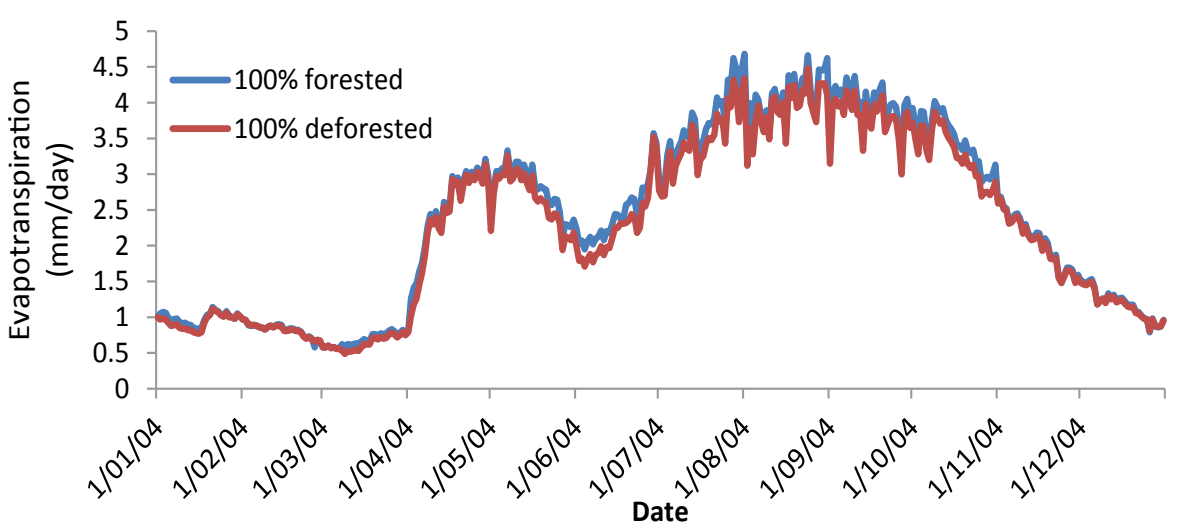

Figure 12: Simulated evapotranspiration for the year 2004 for the completely forested and completely deforested land cover scenarios.

to the 1986 land use, while the dry and small rainy season daily mean stream flow showed variability in the differences.

\section{Discussions}

If the land use-cover change in the entire basin is very small, clearly the stream flow at the basin outlet usually is insensitive to land use cover change [36]. Based on a study in the Rhine basin, the hydrological regime of the basin is expected to shift from a combined snowmeltrainfall regime to a more rainfall-dominated regime and land use change may reinforce the effect of the shift along with all projected land use change scenarios indication of increased stream flow [36].The decrease in stream flow in forestland can be attributed to the higher rate of water loss by evapotranspiration relative to the agricultural land [37]. Deep roots of trees can draw more moisture from the soil more than shallow rooted agriculture plants or bare soil. Besides, deciduous forest has a larger leaf area to transpire [37]. Based on a study in the Xinjiang River basin, China, an increase in stream floww as reported in the wet season and a decrease in stream flow in the dry season due to the land use change from forest into agricultural land [37]. Similarly, the studies that were carried out in the Angereb watershed (in the north) and in the Hare watershed (in the southern) parts of Ethiopia stated that the stream flow for the wet months had increased, while there was a decrease in the dry season due to the land use change $[5,38]$.

The peak flow could also increase, for instance, due to land degradation, urbanization, which leads to a reduction of infiltration and storage. Studies carried out in different regions indicated that these processes lead to an increase in peak flow particularly in the rainy season and either a decrease or an increase of base flow particularly, in the dry season $[4,39,40]$. Similarly, based on a study carried out in Indonesia by Narulita [41] indicated that there was a constant baseflow decrease and a high flow increase after rapid land use change from natural vegetation cover to agricultural land. Overall, most of the studies conclude that there is a stream flow increase including peak flow, particularly in the main rainy season; however, in the dry season, there is inconsistence change in stream flow including baseflow, due to the land use change in a basin. According to Bewket and Strek [4] a study in Chemoga sub basin in north Ethiopia, the hydrology of a sub basin has been influencing negatively due to the clearance of natural vegetation cover, land degradation, and expanded agricultural land that reduce infiltration, decrease groundwater recharge, and increase runoff.

\section{Conclusions and Recommendations}

The analysis of impact of land use-cover change showed that there was a slightly higher stream flow for the 2003 land cover as compared to the 1986 land cover. In the case of the 1986 land cover type, a larger part of the rainfall was lost to evapotranspiration and that is why the stream flow was slightly lower than for the 2003 land cover, especially in the main rainy season. The dry season stream flow for the 2003 land use showed a decreasing magnitude in most of the months as compared to the 1986 land cover.For the main rainy season, the completely nonforested scenario showed that the daily mean stream flow increased by $2 \%$ in June, $13 \%$ in July, $14 \%$ in August and $7 \%$ in September as compared to the completely forested Melka Kuntrie sub basin. These implied that there were $0.01,0.23,0.35$, and $0.12 \mathrm{~mm} /$ day increase of daily mean stream flow for June, July, August, and September, respectively due to the complete deforestation relative to the complete forested one. During the main rainy season, there was slightly increased stream flow for the 2003 land use as compared to the 1986 land use due to the expansion of agriculture land. For the dry season, the simulated stream flow for the 1986 and 2003 land use showed some variability in the flow differences.

The HBV model performance based on the Nash-Sutcliffe efficiency (NS) in the Melka Kuntrie sub basin was reasonably well. There was also a strong seasonal effect in the sub basin that sometimes increases the Nash-Sutcliffe efficiency or correlation coefficient.

\section{Recommendations}

Further research activities should be consider using different hydrological models in the region for the sake of further investigation of the impact of land use-cover change on the hydrology of sub basin.

There should be better land management programs or practices that encourage afforestation so that precipitation during the rainy season could easily infiltrate and recharge groundwater.

There should be strong encouragement and support in rainwater harvesting, afforestation, water and soil conservation practice in community level.

Land use-cover change hazard awareness at all levels (community, locall, regional and national levels) and appropriate response techniques.

It is recommendable to have more hydrometeorological data 
Citation: Getahun YS, Van Lanen HAJ (2015) Assessing the Impacts of Land Use-Cover Change on Hydrology of Melka Kuntrie Subbasin in Ethiopia, Using a Conceptual Hydrological Model. Hydrol Current Res 6: 210. doi:10.4172/2157-7587.1000210

Page 11 of 11

measurement instruments in and around the sub basin that could provide adequate data with better quality.

Better data gathering techniques and dissemination process should be foreseen so that local and regional authorities can be involved in integrated and coordinated manner.

\section{Acknowledgement}

The authors gratefully appreciate to Ethiopian Ministry of Water and Energy (MoWE), and Ethiopian National Meteorology Service Agency (NMSA) for providing hydrometeorologicaland GIS data.

\section{References}

1. Tufa DF, Abbulu Y, Srinivasarao GVR (2014) Watershed Hydrological response to changes in land use/cover pattern of River Basin: A review. International Journal of Civil, Structural, Environmental and Infrastructure Engineering Research and Development 4: 157-170.

2. Hamza IA, Iyela A (2012) Land use pattern, climate change, and its implication for food security inEthiopia: Review. Ethiopia journal of environmental study and management 5: 1

3. Legesse D, Coulomb CV, Gasse F (2003) Hydrological response of a catchment to climate and land use changes in Tropical Africa: case study South Central Ethiopia. Journal of Hydrology 275: 67-85.

4. Bewket W, Sterk G (2005) Dynamics in land cover and its effect on stream flow in the Chemogawatershed, Blue Nile basin. Ethiopia, Hydrol Process 19 445-458

5. Kassa Tadele, GerdFörch (2007) Impact of Land Use/Cover Change on Streamflow: The Case of Hare River Watershed, Ethiopia. Catchment and Lake Research LARS

6. Diress Tsegaye, Moe Stein R, Paul Vedeld, Aynekulu E (2010) Land-use/cover dynamics in Northern Afar rangelands, Ethiopia. Agriculture, Ecosystems and Environment 139: 174-180.

7. Gerold D, DagnachewNegesse (2012) Land Use Land Cover Change in the Katar Catchment, Ziway Watershed, Etiopia.

8. Daniel Ayalew M (2008) Remote sensing and gis-based Land use and land cover change detection in the upper Dijoriver catchment, Silte zone, southern Ethiopia.

9. Daniel Shewangizaw, Yonas Michael (2010) Assessing the Effect of Land Use Change on the Hydraulic Regime of Lake Awassa. Nile Basin Water Science\& Engineering Journal 3.

10. Getachew Haile E, MelesseAssefa M (2012) The impact of land use change on the hydrology of the Angereb Watershed, Ethiopia. International Journal Water Science.

11. Byragi RT, Mekonen Aregai (2011) Effect of Land Cover Dynamics and the Relative Response to Water Resources in Middle Highland Tigray, Ethiopia: the Case of Areas AroundLaelay-Koraro 2: 868-873.

12. Bishaw B (2003) Deforestation and land degradation on the Ethiopian highlands: A strategy for physical recovery 8: 7-25.

13. Shimelis G, Setegn, David Rayner, Melesse Assefa M, BijanDargahi, et al (2011) Climate Change Impact on Agricultural Water Resources Variability in the Northern Highlands of Ethiopia. SpringerScience Business Media.

14. Kassa, TadeleMengistu (2009) Watershed Hydrological Responses to Changes in Land Use and Land Cover, and Management Practices at Hare Watershed, Ethiopia.

15. Gwate O, Woyessa Yali E, David Wiberg (2015) Dynamics of Land Cover and Impact on Stream flow in the Modder River Basin of South Africa: Case Study of a Quaternary Catchment. International Journal of Environmental Protection and Policy 3: 31-38.

16. DeFries R, Eshleman KN (2004) Land-use change and hydrologic processes: a major focus for the future. Wiley InterScience, Hydrol. Process 18: 2183-2186.

17. Tubiello (2007) Land and water use options for climate change adaptation and mitigation in agriculture. New York: FAO.

18. Agarwal A (2002) Integrated Water Resources Management. Stockholm Global Water Partnership (GWP).
19. Kurkura (2011) Water balance of Upper Awash Basin based on satellitederived data Addis Ababa.

20. Behailu, Shimelis (2004) Stream flow simualtion for the Upper Awash Basin Addis Ababa.

21. NASA (2006) How Landsat Images are made. NASA's Landsat, Education and Public Outreach team.

22. Federico Moran (2011) Land Cover Classification in a Complex Urban-Rural Landscape. PhotogrammEng Remote Sensing.

23. James (2001) Band combinations.

24. Paranjape RB, Morrow WM, Rancayan RM (1992) Adaptive-Neighborhood Histogram Equalization for Image Enhancement, Graphical models and image processing 54: 259-267.

25. Manpreet, KaurJasdeep Kaur, Jappreet Kaur (2011) Survey of Contras Enhancement Techniques based on Histogram Equalization. International Journal of Advanced Computer Science and Applications.

26. Krishna Bahadur KC (2009) Improving Landsat and IRS Image Classification: Evaluation of Unsupervised and Supervised Classification through Band Ratios and DEM in a Mountainous Landscape in Nepal. Remote Sensing 1: 12571272.

27. Tammy, James (2013) Classification of a Landsat Image (Supervised), Remote Sensing Analysis in an ArcMap Environment.

28. Chao, Zhongfu (2005) Brightness Preserving Histogram Equalization with Maximum Entropy: A Variational Perspective. IEEE Transactions on Consumer Electronics 51: 1326-1334.

29. Congalton RG (1991) A review of assessing the accuracy of classifications of remotely sensed data. Remote Sensing of Environment 37: 35-46.

30. Yuan F, Bauer ME, Heinert NJ, Holden GR (2005) Multi-level land cover mapping of the Twin Cities (Minnesota) metropolitan area with multi-seasonal Landsat. Geocarto. Int 20: 5-14.

31. Taddese G, Sonder K, Peden D (2006) The water of the Awash River Basin a future challenge to Ethiopia. International Livestock Research Institute. Addis Abeba, Ethiopia.

32. Romilly, Gebremichael (2010) Evaluation of satellite rainfall estimates over Ethiopian river basins. Hydrol. Earth Syst Sci 15: 1505-1514.

33. Degefu W (1987) Some aspects of meteorological drought in Ethiopia, Cambridge University Press.

34. Alemayehu, Mengistu (2006) Country Pasture/Forage Resource Profiles.

35. Nederveen, Coenraads S (2010) Flood Recession Farming: An Overview and Case Study from the Upper Awash Catchment, Ethiopia. VU University.

36. Hurkmans RTWL, Terink W, Uijlenhoet R, Moors EJ, Torch PA, et al. (2009) Effects of land use changes on streamflow generation in the Rhine basin Water resources research 45: 1-15.

37. Guo H, Qi Hu, Tong Jiang (2008) Annual and seasonal stream flow responses to climate and land-cover changes in the Poyang Lake basin, China. Journal of Hydrology 355: 106-122.

38. Getachew, Melesse (2013) The Impact of Land Use Change on the Hydrology of the Angereb Watershed, Ethiopia. International Journal of Water Sciences.

39. Rientjes THM, Perera JBU, Haile AT, Gieske ASM, Booij MJ, et al. (2011) Hydrological Balance of Lake Tana, Upper Blue Nile Basin, Ethiopia. Nile River Basin: Hydrology, Climate and Water Use 69.

40. Costa MH, Botta A, Cardille JA (2003) Effects of large-scale changes in land cover on the discharge of the Tocantins River, Southeastern Amazonia. Journal of Hydrology 283: 206-217.

41. Narulita I (2012) Streamflow fluctuation and land use changes in Bandung Basin. Retrieved 5 50, 2014, from Royal Netherlands Meteorogical instistiute, International workshop climate data, climate change anlysis DIDAH project. 